\title{
THE RELATIONSHIP AMONG E-MARKETING STRATEGY AND SUCCESS OF INTERNATIONALIZATION PROCESS OF THE SMES IN EMERGING ECONOMIES
}

Neringa Ivanauskiene', Vilte Auruskeviciene", Lineta Ramoniene'"I, Vida Skudiene ${ }^{\mathrm{IV}}$

ISM University of Management and Economics, Kaunas, Lithuania

\section{ABSTRACT}

In the last decades, remote technologies changed the networks and communication behavior of a company. Although the number of researches analyzing the importance of Internet to the expansion abroad is constantly growing (Gilmore, Gallagher, \& Henry,2007), the influence of e-marketing strategy on the success of internationalization process remains an unexplored scientific topic. The known theories of firm's internationalization are not able to set the light on the speed and success of internationalization process from the Internet technologies and e-marketing perspective. Therefore, this article presents an empirical testing of Revisited Internationalization Model (Skudiene, Auruskeviciene, \& Sukeviciute, 2015) and a quantitative analysis of the relationship among emarketing strategy and success of internationalization

\section{JEL CLASSIFICATION \& KEYWORDS}

- M16 - M31 $\square$ INTERNATIONALIZATION $\square$ E-MARKETING STRATEGY ॥ SMALL AND MEDIUM SIZE ENTERPRISES

\section{INTRODUCTION}

The Internet changed the rules of the marketing - companies and consumers are interacting online, via virtual networks more often (Tseng, Kuo, \& Chen,2013). The Internet and communication technologies (ICT) became a new and convenient channel to find new customers, partners and suppliers abroad (Chailom, 2012). It also helps small and medium enterprises (SMEs) to communicate globally and expand more freely (Gilmore et al., 2007). Therefore recent years have witnessed the growing interest of researches to examine the role of e-marketing in global expansion of a company. However, the existing internationalization theories (e.g. Uppsala model) have not integrated e-marketing perspective so far (Skudieneet al., 2015).

Considering the above mentioned issues, this study intends to evaluate empirically the influence of e-marketing strategy on the success of firm's internationalization process. Most researches use the concept of Internet-based marketing and e-marketing interchangeably, however for the purpose of this study we define e-marketing as extended traditional marketing practices while using all possible Internet based and other remote ICT technologies (Gilmore et al., 2007).

- The aim of the research is to report on the Revisited Internationalization Model, proposed by Skudien et al. (2015) and test it in the SMEs context. Based on recommendations of European Commission, the purpose of this paper SME is defined as an enterprise which employs more than 10 and fewer than 250 employees, and which have an annual turnover from 10 to 50 million euro.

\section{neriva@ism.lt}

"vilaur@ism.It

III linram@ism.It

Iv vidsku@ism.It

www.journals.cz
A quantitative research approach was adopted using F2F and online interview with structured questionnaire. Representatives of small and medium enterprises were involved in the study.

\section{Theoretical Foundation For The Research}

Although the number of researches on the role of Internet grow significantly (Gilmore et al., 2007), there is scarcity of studies on e-marketing within multinational context (Singh, Gordon, \& Purchase, 2006). ICT technologies allowed SMEs to enhance marketing activities and reduce the borders for expansion (Koenig \& Wigand, 2004). The most-known internationalization theories state that a company has to expand incrementally and rationally, taking into account product and market life cycle reasons, transaction costs, gained experience and knowledge about foreign markets, etc. (Johanson \& Vahle, 1977). Contrary, emerging literature on internationalization stress the effect of technologies on more rapid internationalization processes. Researchers agree that e-marketing strategy is a driver for the success of company internationalization (Eid, 2005), however the discussion regarding the antecedents of internationalization exists.

According to Skudieneet al.,(2015) the antecedents of firm's internationalization, such as: information availability, information usage, international mindset, international business networks, communication interactivity should be integrated into the research models.

The researchers agree that internationalization is a complex and multifaceted construct and the goals of it can be classified as follows: institutional-economic, learning, strategic competition and inter-organization (Rask, Strandskov, \& Hakonsson, 2008). For the purpose of this particular study we adopt inter-organization network approach and analyze the antecedents of internationalization process from that perspective. The literature states that knowledge and experience sharing is a key for the enhancement of expansion process (Luostarinen \& Welch, 1990; Aspelund \& Moen, 2004; Siegel, 2004), with a possibility to access information companies less rely on their resources (Luo, Zhao, \& Du,2005). As the era of ICT technologies allowed the marketers to gain the information instantly it will fasten the internationalization, therefore is assumed that the information availability and usage are antecedents of internationalization.

Companies are likely to expand at a fast pace and communication in social / business networks can help them to gain necessary knowledge and experience. Researchers suggest that business network expansion leads a company to internationalization decisions (Johanson \& Mattson, 1988) and intensive inter-networking communication helps in understanding where and how to expand (Luo et al., 2005). That let us view international business networking and communication as antecedents of internationalization. 
Traditional internationalization theories state that before the decision to go abroad, firms have to create a solid home base (Johanson \& Vahle, 1977; Welch \& Loustarinen, 1988). In our research we adopt the contrary approach of Luo et al. (2005), which states that the incremental speed of internationalization do not fit for small and medium Internetenabled businesses. It could be stated that for successful expansion abroad companies have to be committed for it. Researchers agree that international mind-set perspective (managers' commitment for being international, e-marketing decisions, etc.) is important for firms (Quelch \& Klein, 1996; Harrison-Walker, 2002; Moen, 2002). Therefore we assume that international mind-set is an antecedent of internationalization (Nummela, Saarenketo, \& Puumalainen, 2004; Levy, O., Beechler, Taylor, \& Boyacigiller, 2007).

We assume that companies have to be oriented toward new technologies in order to expand more rapidly and successfully. When company ensure transactions, communication and - information exchange through the Internet in real-time, then it has not rely on local resources heavily (Luo et al., 2005). The firm's web site as a channel for communication with the customers, suppliers and partners permits to cross the borders of distance and more rapidly respond to the needs of foreign markets.

Building on deep literature analysis we can conclude that e-marketing strategy and e-marketing tactics related factors (firm's web characteristics and firm's orientation toward technologies) are the drivers for the success of internationalization process.

The provided analysis let us propose the theoretical model of relationship among e-marketing strategy and internationalization process success which will be tested empirically (Figure 1).

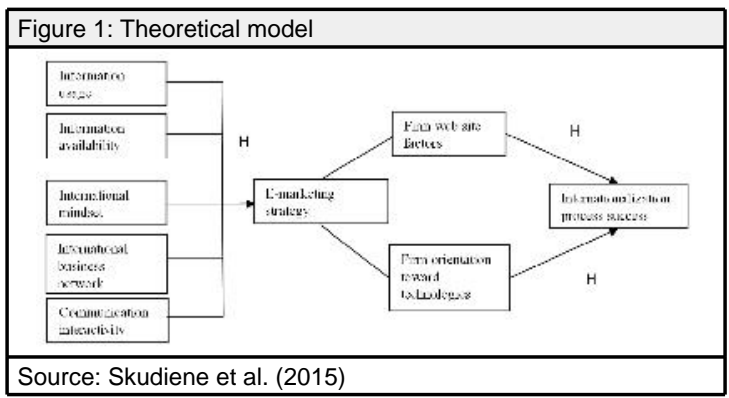

\section{Research Methodology}

Data Collection

This paper aimed to explore the relationship between antecedents of internationalization (information availability and usage, international mindset, international business networks and communication interactivity) and e-marketing strategy and tactics that lead to the success of internationalization process.

In order to achieve the aim we adopted quantitative research. The SMEs in Baltic countries (emerging markets) were selected for the research sample. The sampling strategy was purposeful sampling. To be eligible for the research the company had to be from Baltic countries, and had to fulfil the criterion of SMEs definition.

Firstly, online questionnaires were created using survey platform. To gather the data links with the online questionnaire were sent to the potential participants. The respondents were restricted from submitting more than one questionnaire from any single computer. Secondly, printed copies of questionnaire were distributed using quantitative face-to-face (F2F) methodology. In order to avoid any errors, data that was collected using F2F approach, was included into on-line survey.

A total of 61 responses were received and 8 of which were excluded for being invalid (those with less than two years of international experience; those with same answer to all questions; and / or those containing more than three missing values). Therefore we finalized with 53 valid responses from the representatives of SMEs.

Variables

Independent variables. After reviewing the literature, the antecedents of internationalization, such as information availability, information usage, international mindset, international business networks, and communication interactivity; were chosen as independent variables for this research.

The literature analysis reveals that international mindset can be analyzed as an antecedent of the success of internationalization process (Nummela et al., 2004; Johanson, 2006; Levy et al., 2007). Based on the arguments of previous researches we hypothesize the positive relationship between International mindset and dependent variable. International mindset will be measured by managerial experience and firm's commitment to go abroad.

Based on previous studies (Cavusgil, 1980; Hamill \& Gregory, 1997; Lord \& Ranft, 2000; Zahra \& Ireland, 2000 ), this research adopted the approach of some authors of an availability of Internet-based information as an important antecedent of internationalization success. Therefore the hypothesis of positive relationship among the Information availability with the success of internationalization process will be checked. Measurements of Information ability will include the possibility to reach an information about foreign customers, competitors, and suppliers.

Despite the availability of the information, companies have to be able to use the information on the foreign markets purposefully in order to expand (Andersen, 1993; Calof \& Beamish, 1995; Inkpen \& Beamish, 1997; Johanson \& Vahlne, 1977; Lord \& Ranft, 2000; Zahra \& Ireland, 2000). Therefore the hypothesis of a positive relationship among information usage and internationalization process success will be tested here. Measurement of information usage will include ability to use the information about new markets and resources.

Taking in mind the incremental process of internationalization as well as an importance of networks and communication for the internationalization of the companies (Coviello \& Munro, 1977; Welch \& Loustarinen, 1988; Johanson \& Mattsson, 1988; Coviello, Brodie, Brookes, \& Palmer, 2003; Chetty \& Blankenburg-Holm, 2000; Loane \& Bell, 2006; Chetty \& Agndal, 2007) we decide to evaluate the positive relationship among international business networking, communication interactivity and internationalization process success. We will measure International business networking by company ability to acquire new customers, to maintain business networks relationship, customer relationships while using ICT technologies.

Therefore, the $\mathrm{H} 1$ hypothesis "Information availability, information usage, international mindset, international business networks, and communication interactivity have a positive relationship with internationalization process success" can be postulated. 
Mediating variables. Skudiene et al., (2015) state that e-marketing is a powerful tool for a company to reach international markets. According to Sigala (2001), Bui, Le, \& Jones,(2006), e-marketing strategy is related to the success of internationalization process. We will measure clarity of firm positioning, effectiveness of e-marketing strategy and marketing plan for entering foreign markets.

Firm's orientation towards technologies as well as firm's web site related factors are closely associated with the firm's commitment to expand internationally (Johanson \& Wiedersheim-Paul, 1975; Johanson \& Vahlne, 1990). Therefore, we tested the hypothesis of the mediating effect of factors related to E-marketing tactics (firm's web site related factors and firm's orientation towards technologies) on the relationship between e-marketing strategy and internationalization process success. Thus, the hypothesis $\mathrm{H} 2$ "The relationship between e-marketing strategy and internationalization process success is mediated by firm's website and firm's orientation towards technologies" is postulated.

Dependent variables. This research defined the Internationalization process success as the opinion of respondents about achievements in the foreign markets.

Control variables. The success of internationalization may be affected by previous firm's experience in the foreign markets. Therefore, the Years of company internationalization and the Number of international offices were used as control variables. Those items are measured when using quasi-interval scales. Firms that had less than two years of internationalization experience were excluded from the research.

Research Instrument

To reduce the method bias, the variables were separated by mixing the questions in the questionnaire and guaranteeing the anonymity of firm's respondents (Podsakoff, MacKenzie, Lee, \& Podsakoff, 2003).

In order to ensure content validity, the indicators selected constructs which were mainly adopted from prior studies. A questionnaire consists of the two main parts. Firstly, part one was related to eight main constructs of the study which stands for dependable and independent variables in the theoretical model. Operationalization of each construct consisted of multi-item scales and designed by a seven point Likert scale from "one" (totally disagree) to "seven" (totally agree). Secondly, part two asks about industry type, years of company internationalization, number of international offices, company turnover and number of employees (while two last questions were used for the evaluation of company's size).
The questionnaire was pre-tested before collecting real data through a pilot study. Ten SMEs managers were selected as pre-test sample respondents.

The objective of factor analysis is to test the convergent validity. Based on principal component analysis extraction method with Varimax rotation (Kaiser-Meyer-Olkin Measure of Sampling Adequacy 0,575; Bartlett's Test of Sphericity Chi-Square 1280,514; Significance 0,000) eight components were extracted.

Besides, the scale was tested by Cronbach Alpha to measure the reliability of the data. Alpha coefficients have value ranging from 0.691 (communication interactivity) to 0.939 (firm's e-marketing strategy) thus internal consistency of the measures is considered well (Nunnally \& Bernstein, 1994).

Results

Table 1 below presents the descriptive statistics and Spearman correlation coefficients for the independent, mediating and dependent variables.

The Spearman correlation coefficients indicate that firm's web site related factors and orientation towards technologies are significantly positively related to the success of internationalization process (Table 1). Firm's e-marketing strategy is significantly positively related to all antecedents of internationalization (Information availability, information usage, communication interactivity, international mind-set, international business network, firm's web site related factors, firm's orientation towards technologies). Thus the $\mathrm{H} 1$ hypothesis is partially confirmed.

Figure 2 below presents the means and the confidence intervals $(\mathrm{Cl})$ of the variables. The study reveals that interactivity of communication $(x=5.71)$ is evaluated higher than other variables when e-marketing strategy is evaluated with lowest mean $(x=4.60)$.

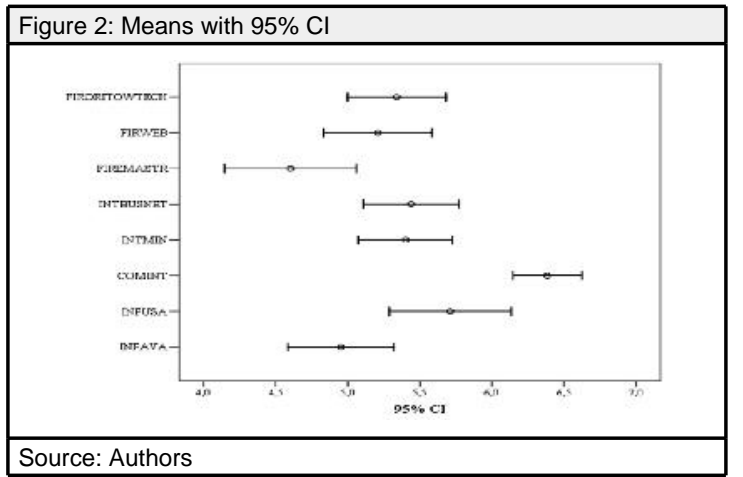

\begin{tabular}{|l|l|l|l|l|l|l|l|l|}
\hline \multicolumn{7}{|l|}{ Table 1: Descriptive Statistics and Spearman Correlation Coefficients } \\
\hline
\end{tabular}


Regression analysis with backward criterion reveals that information availability, information usage and international mind-set are the strongest significant predictors of firm's e-marketing strategy (Table 2).

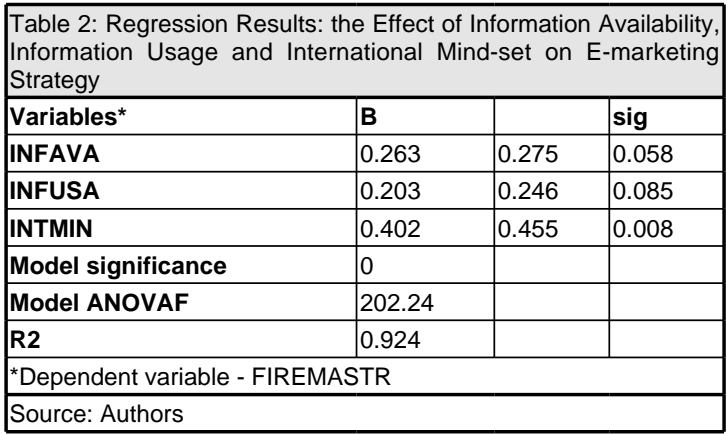

With regards to mediating effect of firm's web factors and firm's orientation toward technologies on the relations between e-marketing strategy and the success of internationalization process, Table 3 below shows that firm's e-marketing strategy have a non-significant negative influence, whereas firm's web site related factors and orientation towards technologies have a significant positive influence on the success of internationalization process.

\begin{tabular}{|l|l|l|l|}
\hline Table 3: Regression Results of Mediating Influence \\
\hline Variables & B & $\boldsymbol{\beta}$ & sig \\
\hline FIREMASTR & -0.215 & -0.255 & 0.1 \\
\hline FIRWEB & 0.426 & 0.415 & 0.004 \\
\hline FIRORITOTECH & 0.366 & 0.325 & 0.033 \\
\hline Model significance & 0.002 & & \\
\hline Model ANOVAF & 5.822 & & \\
\hline R2 & 0.263 & & \\
\hline${ }^{\star}$ Dependent variable - INTPROSUC \\
\hline Source: Authors
\end{tabular}

Based on regression analysis it could be concluded that the hypothesis $\mathrm{H} 2$ "The relationship between e-marketing strategy and internationalization process success is mediated by e-marketing tactics - website design and firm's orientation towards technologies" is confirmed.

\section{CONCLUSION}

We adopted the Revisited Internationalization Model, proposed by Skudiene et al., (2015) and empirically evaluated the relationship among e-marketing strategy and internationalization process success. The relations between antecedents of internationalization process (information availability, information usage, international mindset, international business networks, and communication interactivity) with e-marketing strategy and the success of internationalization process were evaluated as well.

The results revealed that communication interactivity was evaluated with the highest mean which does not contrast with the basic assumptions of Arnot \&Bridgewater (2002) Thus, the outcomes indicate that when companies are expanding internationally they are mainly focused on remotely sharing knowledge and experience between customers, suppliers and partners.

It was unexpected that the information availability was given a lower mean than information usage. This finding suggests that companies are not yet able to use ICT technologies for finding necessary information. However information availability plays a pivotal role in influencing information www.journals.cz usage (Johanson \& Vahle, 1977). Thus, the findings suggest that business enterprises need to focus on information availability in order to successfully expand abroad.

In line with preceding research (Aspelund \& Moen, 2004) the findings indicate that information availability, information usage and international mindset constitute significant determinants of e-marketing strategy.

Further the study enriches the internationalization literature by providing empirical evidence regarding e-marketing and internationalization success inter-relations. The results show that the relationship between e-marketing strategy and internationalization process success is mediated by the effect of factors, related with e-marketing tactics.

The current findings provide several managerial implications to SMEs in emerging markets (Baltic countries in this case). In order for SMEs to effectively internationalize they have to invest in e-marketing strategy and dedicate the efforts to the tactical solutions - web site design and orientation toward technologies. Adopting e-marketing strategy and capabilities could increase their business performance in foreign markets. To survive in the global market SMEs must continuously upgrade online business systems. Furthermore, e-marketing adoption is crucial success factor for operating in international arena.

Further Research Recommendations

In order to make generalizations with confidence, future research is needed to test the proposed model in various countries and with bigger sample. Although the evaluated performance in this research is close to other investigations, it indicates that a significant portion of variation in performance remains unexplained. Thus, other important variables should be included to the model in order to explain e-marketing role in companies' internationalization process.

Furthermore, a valid measure of e-marketing factors is needed to capture the main dimensions of the concept as only a generic measures suggested by Brodie et al. (2007) and Brady, Saren, \& Tzokas (2002) have been used so far in literature.

Finally, future endeavors should investigate other Internet marketing capabilities and their influence on internationalization process success.

\section{Acknowledgement}

This research was funded by a grant (No. MIP-014/2013) from the Research Council of Lithuania.

\section{REFERENCES}

Andersen, O. (1993). In the internationalization process of the firm: A critical analysis. Journal of International Business Studies, 24(2), 209-231.

Arnott, D.,\& Bridgewater,S. (2002). Internet, interaction, and implications for marketing. Marketing Intelligence Planning, 20(2), 86-95.

Bui, T.X., Le, T.,\& Jones, D.W. (2006). An exploratory case study of hotel e-marketing in Ho Chi Minh City. Thunderbird International Business Review, 48(3), 369-388.

Aspelund, A.,\& Moen, O. (2004). Internationalization of small high-tech firms: the role of information technology. Journal of Euro-Marketing, 13(2/3), 85-105.

Brady, M., Saren, M., \& Tzokas, N. (2002).Integration information technology into marketing. Journal of Marketing Management, 18(5/6), 555-578.

Brodie, R.J., Winklhofer, H., Coviello, N.E.,\& Johanton, W. (2007). Is e-marketing coming of age? An examination of the penetration of e-marketing and firm performance. Journal of Interactive Marketing, 21(1), 2-21. 
Calof, J. \& Beamish, P. (1995). Adapting to foreign markets: explaining internationalization. International Business Review,4(2), $115-131$

Cavusgil, S.T. (1980). On the internationalization process of the firms'. European Research, 8, November, 273-281.

Chailom, P. (2012). Antecedents and consequences of E-marketing Strategy: Evidence from E-commerce Business in Thailand. International Journal of Business Strategy, 12(2), 75-87.

Chetty, S., \& Agndal, H. (2007). Social capital and influence on changes in internationalization mode among small and medium-sized companies. Journal of International Marketing, 15(1), 1-29.

Chetty, S.K.,\& Blankenburg-Holm, D. (2000). Internationalization of small and medium-sized manufacturing firms - a network approach. International Business Review, 9, 77-93.

Coviello, N.,\& Munro, H. (1977). Network relationships and internationalization process of small software firms. International Business Review, 6(4), 361-386.

Coviello, N.E., Brodie, R.J., Brookes, R.W.,\& Palmer, R.A. (2003) Assessing the role of e-marketing in contemporary marketing practice. Journal of Marketing Management, 19, 857-881.

Eid, R. (2005). International Internet Marketing: a Triangulation study of Drivers and Barriers in the Business-to-Business Context in the United Kingdom. Journal of Marketing Intelligence and Planning, 23(3), 266-280.

Gilmore, A., Gallagher, D., \& Henry, S. (2007). E-marketing and SMEs: Operational Lessons for the Future. European Business Review, 9(3), 234-247.

Hamill, J. \& Gregory, K. (1997). Internet marketing in the internationalization of UK SME's. Journal of Marketing Management, 13(1-3), 9-28.

Harrison-Walker, J. (2002). If you build it, will they come? Barriers to international e-marketing. Journal of Marketing, Theory and Practice, 10(2), 12-21.

Inkpen, A.,\& Beamish, P. (1997). Knowledge bargaining power and the instability of international joint venture. Academy of Management Journal,22(1), 177-202.

Johanson, J.,\& Mattson, L. (1988). Internationalization in industrial systems - A network approach. In N. Hood\&J.-E. Vahle (Eds.), Strategies in global competition (pp. 287-314). London: Croom Helm.

Johanson, J.,\& Vahle, J.-E. (1977). The internationalization process of the firm - A model of knowledge development and increasing foreign market commitments. Journal of International Business Studies, 8(1), 23-32.

Johanson, J.,\& Wiedersheim-Paul, F. (1975). The internationalization of the firm: four Swedish cases. Journal of Management Studies,12(3), 305-322.

Johanson, J., \& Vahle, J.-E. (1990). The mechanism of internationalization, International Marketing Review, 7(4), 11-24.

Koenig, W., \& Wigand, R.T. (2004). Globalization and E-commerce: Diffusion and Impacts of the Internet and E-commerce in Germany. Digest of Electronic Commerce Policy and Regulation, 27, 197-227.

Levy, O., Beechler, S., Taylor, S., \& Boyacigiller, N. (2007). What we talk about when we talk about global mindset: managerial cognition in multinational corporations. Journal of International Business, 38(2), 231-258.

Loane, S. \& Bell, J. (2006). Rapid internationalization among entrepreneurial firms in Australia, Canada, Ireland and New Zealand: an extension to the network approach. International Marketing Review, 23(5), 467-487.

Lord, M. \& Ranft, A. (2000). Organizational learning about new international markets: exploring the internal transfer of loca market knowledge. Journal of International Business Studies, 31(4), 573-589.

Luo, Y., Zhao, J.H., \& Du, J. (2005). The Internationalization Speed of E-commerce Companies: an Empirical Analysis. International Marketing Review, 22(6), 693-709.

Luostarinen, R. \& Welch, L. (1990). International Business Operations. Helsinki: Exporting Consulting.

www.journals.cz
Moen, O. 2002. The Internet and international marketing: an empirical analysis of small and medium sized Norwegian firms. Quarterly Journal of Electronic Commerce, 3(1), 31-41.

Nummela, N., Saarenketo, S., \& Puumalainen, K. (2004). A global mindset - a prerequisite for successful internationalization. Canadian Journal of Administrative Sciences, 21(1), 51-64.

Nunnally, J.C., \& Bernstein, I.H. (1994). Psychometric Theory. New York: McGraw-Hill.

Podsakoff, P.M., MacKenzie, S. B., Lee, J.-Y.,\& Podsakoff, N.P. (2003). Common method biases in behavioral research: a critical review of the literature and recommended remedies. Journal of Applied Psychology, 88(5), 879-903.

Quelch, J. \& Klein, L. (1996). The Internet and international marketing. Sloan Management Review, 37(3), 60-76.

Rask, M., Strandskov, J.,\& Hakonsson, D.D. (2008). Theoretical Perspectives on the Internationalization of Firms. Journal of Teaching in International Business, 19(4), 320-345.

Siegel, C. (2004). Internet marketing: foundations and applications. Boston: Houghton Miffin.

Sigala, M. (2001). Modelling E-Marketing Strategies: Internet Presence and Exploitation of Greek Hotels. Journal of Travel \& Tourism Marketing, 11(2-3), 83-103.

Singh, T., Gordon, G., \& Purchase, S. (2006). B2B Marketing Strategies for Multinational Corporations: Empirical Evidence from the United States and Australia. Mid-American Journal of Business, 22(1), 31-44

Skudiene, V., Auruskeviciene, V., \& Sukeviciute, L. (2015). Internationalization model revisited: e-marketing approach. ProcediaSocial and Behavioral Sciences. 20th International Scientific Conference Economics and Management-2015 (ICEM-2015)

Tseng, C.-H., Kuo, H.-C., \& Chen, J.-M. (2013, April). The Relationship Among Advertisement, Electronic Word of Mouth, and Purchase Intention on Virtual Community Members. 2013 Northeas Decision Sciences Institute Annual Meeting Proceedings, 129-148.

Welch, L.S., \& Loustarinen, R.K. (1988). Internationalization: evolution of a concept. Journal of General Management, 14(2), 36-64.

Zahra, S.,\& Ireland, R. (2000). International expansion by new venture firms: international diversity, mode of market entry, technology learning and performance. Academy of Management Journal, 43(5), 925-950. 